University of Maryland Francis King Carey School of Law

DigitalCommons@UM Carey Law

4-1-1995

\title{
Genetic Information and Health Insurance: State Legislative Approaches
}

Karen H. Rothenberg

University of Maryland School of Law, krothenberg@law.umaryland.edu

Follow this and additional works at: https://digitalcommons.law.umaryland.edu/fac_pubs

Part of the Health Law and Policy Commons

\section{Digital Commons Citation}

Rothenberg, Karen H., "Genetic Information and Health Insurance: State Legislative Approaches" (1995).

Faculty Scholarship. 154.

https://digitalcommons.law.umaryland.edu/fac_pubs/154

This Article is brought to you for free and open access by the Francis King Carey School of Law Faculty at DigitalCommons@UM Carey Law. It has been accepted for inclusion in Faculty Scholarship by an authorized administrator of DigitalCommons@UM Carey Law. For more information, please contact smccarty@law.umaryland.edu. 


\title{
Genetic Information and Health Insurance: State Legislative Approaches
}

\author{
Karen H. Rothenberg
}

We may create a catch-22 so that only people who are unlikely to need health insurance can afford it.... Generic risk testing is important because it exposes the logic of a system that provides access to health insurance to those least likely to need it. ${ }^{1}$

$\mathrm{T}$ he fear of genetic discrimination ${ }^{2}$ in the health insurance contex $t^{3}$ cannot be underestimated. Some have argued that individuals who might otherwise choose generic testing will decline it based on their fear that they or their family members will not be able to obtain or maintain health insurance coverage. ${ }^{4}$ As a result, the future of research on the benefits and risks of testing for genetic conditions, including suscepribility to such common diseases as cancer and hearr disease, may also be inhibited. Thus, as the mapping of the human genome progresses and new generic tests proliferate, policy makers need to evaluate the legislative and regulatory strategies to address these concerns.

Toward this goal, this arricle summarizes and analyzes state legislation on genetic information and health insurance. It also highlights the major policy considerations that must be addressed in order to reach consensus on furure strategies. This article must be read in context with broader state health insurance reforms and privacy legislation, as well as important federal legisiarive and regulatory approaches that affect health insurance and discrimination issues.

\section{The context of insurance ${ }^{6}$}

Group insurance, individual insurance, self-insurance, and publicly financed insurance (that is, Medicare or Medic-

Journal of Law, Medicine of Ethics, 23 (1995): 312-19. (C) 1995 by the American Sociery of Law, Medicine \& Ethics. aid) represent the primary mechanisms for obtaining health insurance in the United States. Most insureds receive their health insurance through their employer, although over forty million Americans, many of whom are employed, remain uninsured. ${ }^{7}$

Group insurance may be offered to employers based on the company's past claims (experience rating) or, as with Blue Cross/Blue Shield plans, on the average cost of a defined region (community rating). Coverage is also obtained through health maintenance organizations (HMOs) and managed care plans, which may be subject to federal HMO regulations on rates, preexisting conditions, underwriting, and other provisions of care.

For small groups and individuals who apply for coverage, commercial insurers underwrite based on personal and family medical history, as well as on risk factors such as age, occupation, and use of alcohohand tobacco. Although state insurance laws prevent "unfair discrimination," this provision has not been interpreted to extend to underwriting based on family and medical history. Furthermore, insurance companies have argued that preventing their access to all medical information will result in adverse selection, by which individuals who know they have a condition, disease, or predisposition to disease may purchase insurance coverage at a premium that will not cover losses.

With increasing frequency, employers provide health insurance benefits through self-funded plans, in which the employer forms its own insurance pool, usually hiring an insurance company to administer its plan. It is estimated that over one-third of the nonelderly insured population throughour this country obtains its coverage through selffunded plans. ${ }^{8}$ Self-funded plans providing private health benefits for employees and their dependents are exempt from state insurance laws pursuant to the Employee Retirement Income Security Act (ERISA) preemption.' Thus, 
these plans need not follow state laws that require health insurance contracts to include certain benefits, limit preexisting conditions, follow antidiscrimination restrictions, or other state health care reforms.

The increasing use of self-funded plans complicates public policy on genetic information and insurance. Even though the McCarran-Ferguson $\mathrm{Act}^{10}$ provides that the states have the major regulatory authority for the business of insurance (and so limits any nationwide attempt at insurance reform), ERISA preemption prevents any comprehensive statewide approach to regulating the use of genetic informarion by all plans providing health benefits. Currenty, no federal legislation addresses genetic information in this context. Furthermore, although the Americans with Disabilities Act of $1990^{11}$ (ADA) protects persons with physical or mental disabilities-including genetic diseases, conditions, and predispositions-from discrimination, ${ }^{12}$ Title $\mathrm{V}$ of the ADA provides that, absent "subterfuge," conventional underwriting of risk by commercial insurers or selfinsured employers does not constitute prohibited discrimination. Thus, any comprehensive strategy to regulate genetic discrimination in health insurance must be evaluated in the context of numerous state and federal regulatory issues.

\section{Evolution of state legislation}

In the 1970 s, a few states began to pass legislation that addressed generics issues. North Carolina, for example, passed legislation prohibiting health insurers from refusing to issue insurance or from charging higher premiums based on sickle cell trait or hemoglobin C trait." Florida passed similar legislation limired to sickle cell trait. ${ }^{14}$ Legislation passed by other states addressed primarily employment, forensics, paternity, and other forms of insurance. Many of these starutes also limired their focus to specific traits and disorders. By 1986, Maryland did pass legislation prohibiting health insurers from rate discrimination based on "sickle-cell trait, thalassemia-minor trait, hemoglobin $C$ trait, Tay-Sachs trait, or any generic tratt which is harmless within itself." ${ }^{\prime \prime s}$ The legislation provided, however, that insurers could continue to use genetic information to discriminate if there was "actuarial justification."

\section{Establishing a new framework}

By 1991, a new generation of state legislation began to evolve with the passage of a $\mathrm{W}_{1}$ sconsin law prohibinng health insurers from:

- requiring or requesting an individual or a member of the individual's family to obtain a genetic test;

- requiring or requesting directly or indirectly into the results of a genetic test;
- conditioning the provision of insurance coverage or benefits on genetic testing; or

- considering genetic testing in determining rates.

This approach attempts to integrate protection against discrimination in insurance practices, coverage, benefits, and rates with some privacy protection for the individual and his/her family. Similar approaches have been incorporated to varying degrees in recent legislation passed in California, ${ }^{17}$ Colorado, ${ }^{18}$ Georgia, ${ }^{19}$ Minnesota, ${ }^{20}$ New Hampshire, ${ }^{21}$ Ohio, ${ }^{22}$ and Oregon, ${ }^{23}$ as well as in bills carrenty pending in Hawaii, ${ }^{24}$ Kansas, ${ }^{25}$ Massachusetrs, ${ }^{26}$ and Pennsylvania. ${ }^{27}$ It is worth noting that Ohio law does provide that an insurer may consider the results of generic testing if voluntarily submitted and the results are favorable to the individual. (See Figures 1 and 2.)

\section{Genetic test defined}

These recently enacted statutes, summarized in Figure 1, focus narrowly on the generic test, rather than on prohibiting discrimination based more broadly on genetic information generared from family history, physical examination, or the medical record. Oregon lawmakers did attempt to address this broader definition, but compromised in prohibiting discrimination based on genetic information that is limited by definition to a genetic test (defined in part as a tesr of a genetic characteristic) or an individual's DNA sample. ${ }^{28}$ California does not define genetic test, rather it prohibits discrimination on the basis of "genetic characteristics," which is defined as "any scientifically or medically identifiable gene or chromosome, or alteration thereof, which is known to be a cause of a disease or disorder, or determined to be associated with a statistically increased risk of development of a disease or disorder, and which is asymptomatic of any disease or disorder."

Regardless of the definition of generic test, this new generation of legislation is not focused on a specific genetic tratt or condition, but on a potentially unlimited number of rests. Wisconsin defines a genetic test as a test using DNA "extracted from an individual's cells in order to determine the presence of a genetic disease or disorder or the individual's predisposition for a particular generic disease or disorder. ${ }^{n 30}$ In the few years since passage of that law, the definition of generic test has evolved, based in part on advancing technologies and medical knowledge, and in part on political compromise. Minnesota, for example, defines genetic test as a "presymptomaric test of a person's genes, gene products, or chromosomes for the purpose of determining the presence or absence of a gene or genes that exhibit abnormalities, defects, or deficiencies, including carrier status, that are known to be the cause of a disease or disorder, or are determined to be associared with a statistically increased risk of development of a disease or disor- 


\begin{tabular}{|c|c|c|}
\hline State & Citation & Description \\
\hline Alabama (1982) & Ala. Stat. 27-5-13 & $\begin{array}{l}\text { Prohibits health insurers from denying coverage because appliant has sickle } \\
\text { cell anemiz. }\end{array}$ \\
\hline California (1995) & $\begin{array}{l}\text { Insur. Code } \int S 10123.3 \text {, } \\
10140,10147, \\
11512.95,10123.31, \\
10123.35,10140.1, \\
10140.5,11.512 .96, \\
11512.965 \\
\text { Health \& Safety Code } \\
\text { SS } 1374.7,1374.9\end{array}$ & $\begin{array}{l}\text { Prohibits health insurance plans from offering or providing different terms, } \\
\text { conditions, or benefits on the basis of genetic characteristic. }\end{array}$ \\
\hline California (1994) & $\begin{array}{l}\text { Insur. Code SS } \\
10123.3,10140 \\
10148,10149 \\
10149.1,11512.95 \\
\text { Heaith \& Safery Code } \\
\text { S } 1374.7\end{array}$ & $\begin{array}{l}\text { Prohibits health insurance plans from refusing to enroll or accept persons } \\
\text { based on generic characteristics. } \\
\text { Prohibits health insurers from imposing a higher rate or charge on the } \\
\text { basis of generic characteristics. } \\
\text { Provides for privacy protection of genetic information. }\end{array}$ \\
\hline Colorado (1994) & $\begin{array}{l}\text { Tit. } 10, \text { art. } 3, \text { pt. Il, } \\
\text { S } 10-3-1104.7\end{array}$ & $\begin{array}{l}\text { Prohibits use of information derived from genetic tesing to deny access to } \\
\text { health care insurance. } \\
\text { Provides for privacy protection of generic information. }\end{array}$ \\
\hline Florida (1978) & Fla. Star. 626.9707 & $\begin{array}{l}\text { Prohibits insurers from refusing to issue and deliver any policy of "disabil- } \\
\text { iry" insurance, which "affords benefits and coverage for any medical treat- } \\
\text { ment or service," solely because a person has the sickle cell trait. } \\
\text { Prohibits a "disability" insurance policy from charging a higher rate solely } \\
\text { because a person has the sickle cell trair. }\end{array}$ \\
\hline Florida (1992) & Fla. Stat. 760.40 & $\begin{array}{l}\text { Provides for informed consent and privacy protection of genetic informa- } \\
\text { tion. } \\
\text { Provides for mandatory reanalysis if use of genetic information results in a } \\
\text { denial of insurance. }\end{array}$ \\
\hline Georgia (1995) & Tit. 33 , ch. 54 & $\begin{array}{l}\text { Prohibits use of genetic testing except to obtain information for therapeutic } \\
\text { or diagnostic purposes. } \\
\text { Provides for written consent prior to generic testing. } \\
\text { Provides for privacy protection of genetic information. } \\
\text { Prohibits health insurers from seeking information derived from generic testing. }\end{array}$ \\
\hline Maryland (1986) & $\begin{array}{l}\text { Insur. Code art. } 48 \mathrm{~A}, \\
\mathrm{~S} 223(\mathrm{~b})(4)\end{array}$ & $\begin{array}{l}\text { Prohibits health insurers from making or permitting differentials in rates } \\
\text { based on any genetic trait, unless actuarially justified. }\end{array}$ \\
\hline Minnesora (1995) & 1995 Minn. Laws 251 & $\begin{array}{l}\text { Prohibits health insurers from using information from generic testing to de- } \\
\text { rermine eligibility, establish premiums, limit coverage, or renew coverage. } \\
\text { Prohibits health insurers from requiring a genetic rest and from inquiring or } \\
\text { determining whether an individual has had a genetic test. }\end{array}$ \\
\hline $\begin{array}{l}\text { New Hampshire } \\
\text { (1995) }\end{array}$ & 1995 N.H. Laws 101 & $\begin{array}{l}\text { Prohibits health insurers from conditioning provision of health insurance } \\
\text { coverage on the results of genetic testing. } \\
\text { Prohibits health insurers from considering generic testing to determine rates } \\
\text { or benefits. } \\
\text { Prohibits health insurers from requiring a genetic test and from inquiring or } \\
\text { determining whether an individual has had a genetic test. }\end{array}$ \\
\hline $\begin{array}{l}\text { North Carolina } \\
\text { (1975) }\end{array}$ & N.C. Sat. S 58-65-70 & $\begin{array}{l}\text { Prohibits health insurers from denying health insurance because an indivi- } \\
\text { dual has sickle cell trait or hemoglobin } C \text { trait. } \\
\text { Prohibits health insurers from charging higher premiums based on sickle cell } \\
\text { trait or hemoglobin } C \text { trait. }\end{array}$ \\
\hline
\end{tabular}

Figure 1. Genetic Information and Health Insurance: Enacted Legislation. 


\begin{tabular}{|c|c|c|}
\hline State & Citation & Description \\
\hline Ohio (1993) & $\begin{array}{l}\text { Oh. Sat. SS } 1742.42 \text {, } \\
1742.43,3901.49 \text {, } \\
3901.491,3901.50 \text {, } \\
3901.501 \\
\text { H. } 71 \text { S 3, Oh. 120th Gen. } \\
\text { Assembly (1993) (enacted) }\end{array}$ & $\begin{array}{l}\text { Prohibits health insurers from canceling, refusing to issue, renewing cover- } \\
\text { age, or limiting benefits based on genetic screening or testing. } \\
\text { Prohibits health insurers from requiring a genetic test or inquiring about } \\
\text { results of genetic screening or testing. } \\
\text { Provides for consideration of genetic testing if results are favorable to the } \\
\text { applicant and volunarily submitred. } \\
\text { Establishes the Task Force on Genetic Testing in Health Insurance. }\end{array}$ \\
\hline Oregon (1995) & 1995 Or. Laws 680 & $\begin{array}{l}\text { Prohibits health insurers from using generic information to reject, deny, limit, } \\
\text { cancel, refuse to renew, increase the rares of, or affect the terms and condi- } \\
\text { tons of health insurance policies. } \\
\text { Provides for informed consent and privacy protection of generic informa- } \\
\text { tion. }\end{array}$ \\
\hline Virginia (1995) & S.J. Res. 372 & $\begin{array}{l}\text { Establishes a subcommittee to study the legal and policy ramifications of } \\
\text { breast cancer susceptibility gene research, including the ethical and legal } \\
\text { issues of health insurance coverage and reimbursement. }\end{array}$ \\
\hline Wisconsin (1991) & Wis. Stat. S 631.89 & $\begin{array}{l}\text { Prohibits health insurers from conditioning provision of insurance coverage } \\
\text { or benefits on genetic testing. } \\
\text { Prohibits use of genetic testing information in determining rates. } \\
\text { Prohibits health insurers from requiring a genetic test or inquiring whether a } \\
\text { genetic test has been performed. }\end{array}$ \\
\hline
\end{tabular}

Figure 1. Continued.

der." ${ }^{31}$ A few states, including California ${ }^{32}$ and New Hampshire, ${ }^{33}$ include reliance on "scientific or medical" acceptance of the genetic test within its definition.

Most recently, a Wisconsin bill which has been introduced significantly expands the definition of genetic test to include "a physical examination of an individual or an examination of the family history of an individual to determine ... whether an individual has a generic disease or disorder ... or is predisposed to a generic disease or disorder. ${ }^{34}$ To prohibit discrimination based on prenatal genetic testing, "individual" is defined to include an unborn child. ${ }^{35}$

\section{Insurance entity defined}

It is difficult to define in any general terms the "insurance" entities covered by these statures, partly because each state defines its jurisdiction pursuant to its own insurance code and regulatory authority. Generally, the statures cover health insurance plans, which may be further delineared as hospital service plans, HMOs, third-party administrators, and government entities providing coverage for health care services on a self-insured basis. New Hampshire boldly extends its definition to include self-insurance plans generally, ${ }^{36}$ even though ERISA is deemed to preempt state insurance regulation for those plans provided by private employers. This statute also provides, as do most of the other statutes, that life and disability income insurance are not included among the insurance entiries prohibited from using generic test results. ${ }^{37}$

\section{Privacy protections integrated}

Concerns over privacy and generic information are addressed to varying degrees in many of the statutes. As noted earlier, the Wisconsin law established that insurers may not "require or request directly or indirectly any individual to reveal whether the individual or a member of the individual's family has obtained a genetic test or what the results of the test, if obtained by the individual or a member of the individual's family, were. ${ }^{38}$ Many of the other state laws and pending bills (in Figures 1 and 2) have also adopted this provision. Ironically, the recent $\mathrm{W}_{1 s c o n s i n}$ bill ${ }^{39}$ that expands the definition of genetic test, deletes this provision. Proponents of the bill believe that as long as state law prohibits the use of genetic information in the underwriting process, health insurers may have legirimate reasons to require or request genetic information. For example, they argue that HMOs, which are both insurers and providers, may need this information to trear the parient and insurers may need access to this information to verify claims. ${ }^{+0}$

Other states have further expanded on privacy issues. California, for example, prohibits disclosure of generic test results to any third party without written authorization. ${ }^{4}$ Written authorization is required for each separate disclosure of genetic test results and must specify the person or entiry to whom the disclosure will be made. Negligent and willful disclosure without authorization are subject to both civil and criminal liability. Colorado specifically provides that information obtained from genetic testing shall be "con- 


\begin{tabular}{|c|c|c|}
\hline State & Citation & Description \\
\hline Hawaii & $\begin{array}{l}\text { S. } 299 ; \text { S. } 576 \text {; } \\
\text { H. } 1556\end{array}$ & $\begin{array}{l}\text { Prohibits health insurers from requiring generic resting or inquiring whether } \\
\text { genetic tesing has been performed. } \\
\text { Prohibits heaith insurers from conditioning provision of coverage or bene- } \\
\text { fits on genetic testing. } \\
\text { Prohibits health insurers from determining rates based on genetic testing. }\end{array}$ \\
\hline Kansas & H. 2251 & $\begin{array}{l}\text { Prohibits health insurers from requiring or requesting directly or indirectly } \\
\text { any individual to obtain a generic test or to reveal whether one has been } \\
\text { performed. } \\
\text { Prohibits health insurers from conditioning provision of coverage or bene- } \\
\text { fits on generic testing. } \\
\text { Prohibits health insurers from determining rates based on generic testing. }\end{array}$ \\
\hline Massachusets & $\begin{array}{l}\text { S. } 2045 \\
\text { H. } 4485\end{array}$ & $\begin{array}{l}\text { Establishes commission to consider appropriate role for state regarding the } \\
\text { use of genetic information, including whether state should take a direet } \\
\text { role in regulating collection, access to, and use of genetic information. } \\
\text { Prohibits health insurers from refusing to enroll any person on the basis of } \\
\text { generic testing. } \\
\text { Prohibits health insurers from imposing a higher rate on the basis of gene- } \\
\text { tic characteristics. } \\
\text { Provides for informed consent and privacy protection of generic informa- } \\
\text { tion. } \\
\text { Prohibits underwriters from seeking or obraining genetic information. }\end{array}$ \\
\hline Michigan & H. 5237 & $\begin{array}{l}\text { Prohibits insurance companies from refusing to insure or limiting coverage } \\
\text { due to refusal to submir to genetic testing or the results of genedic testing. }\end{array}$ \\
\hline Nebraska & L. 698 & $\begin{array}{l}\text { Establishes commission to study the use of human genetic information and } \\
\text { ies impact on insurance. }\end{array}$ \\
\hline Pennsylvania & H. 1662 & $\begin{array}{l}\text { Prohibits health insurers from requiring or requesting directly or indirectly } \\
\text { any individual to obtain a genetic test or to reveal whether one has been } \\
\text { obtained and, if so, its results. } \\
\text { Prohibits health insurers from conditioning provision of coverage on gene- } \\
\text { tic testing. } \\
\text { Prohibits health insurers from determining rates based on genetic resting. }\end{array}$ \\
\hline$W_{1 s c o n s i n}$ & A. 227 & $\begin{array}{l}\text { Broadens the current state definition of generic test to include physical ex- } \\
\text { amination or family history. } \\
\text { Removes current prohibitions against requiring or reguesting an individual } \\
\text { to obtain a generic test or to reveal whether one has been obtained and, if } \\
\text { so, its resuls. } \\
\text { Maineains the prohibitions against conditioning insurance coverage or } \\
\text { determining rates based on genetic testing. }\end{array}$ \\
\hline
\end{tabular}

Figure 2. Genetic Information and Health Insurance: Pending Legislation as of December 31, 1995.

fidential and privileged, ${ }^{\prime 12}$ and Oregon and Georgia establish that genetic information is the "property of the individual. ${ }^{n 3}$ Nevertheless, they both provide, as do a number of the other states, for specific exceptions in which written authorization is not required for disclosure (that is, paternity, criminal proceedings, or health department protocols). Even when these statutes require informed consent prior to genetic testing, they do not address whether the informed consent process will incorporate a warning that the test results may be disclosed without authorization under certain circumstances.
A Florida law passed in 1992 also permits DNA analysis to be used withour informed consent in criminal prosecuions, other criminal matters, and paternity determinations. ${ }^{4}$ Except in these circumstances, the statute declares that the test results are the exclusive property of the person tested, are confidential, and may not be disclosed without consent. Nevercheless, the statute does not prohibit the use of genetic information in determining health insurance coverage and benefits. If DNA test results are used in any decision to grant or deny insurance, the individual must be notified, and the analysis must be repeated to verify its accuracy. 
Some scanutes address privacy issues created by access to shared insurance data bases. The $W_{1 s c o n s i n}{ }^{45}$ and New Hampshire 46 laws provide that insurers writing life and disability income insurance in addition to health insurance cannot use genetic test information to underwrite their health insurance policies. In Minnesota, where a life insurance company may require a genetic test, the stature provides that written informed consent must include information on the uses and limizations of the test, as well as the individual's right to confidential treatment of the information. ${ }^{47}$ It is worth noting that the Minnesota statute specifically provides that "[if] the individual tested has not given written consent authorizing the physician to receive the test results, the individual must be urged at the time that the individual is informed of the genetic test results ... to contact a genetic counselor or other health care professional. ${ }^{n 8}$ Similar provisions are included in the California statute ${ }^{49}$ and the Massachusetrs bill..$^{\text {so }}$

\section{Study groups established}

Over the last few years, a number of scates, most recently Nebraska, ${ }^{51}$ Ohio, ${ }^{52}$ and Virginia, ${ }^{53}$ have passed legislation

$\therefore$... to establish task forces or commissions to study the policy and societal issues raised by genetic information. The state of Virginia specifically provides for a subcommittee to study the legal and policy ramifications of breast cancer susceptibility gene research, including the ethical and legal issues of health insurance coverage and reimbursement.

\section{Other legislative experiences}

Recently, a number of other states have attempted to pass withour success legislation addressing genetic discrimination and health. Proposals often failed because of splits along political party lines. In Texas, ${ }^{54}$ the generic discrimination and insurance bill failed in commirtee despite a compromise that would have removed disability income and life insurance. When the bill was put to a committee vote, two liberal members refused to suppor the bill because it was limited only to heaith insurance. In fact, in a number of the states that have enacted legislation, bills were passed only after life and/or disability income insurance were excluded. New York State has attempted legislation to address health insurance issues as part of a comprehensive omnibus bill addressing numerous generic discrimination issues.ss This approach has nor achieved support, and the legislature is now considering other bills limited to one issue at a time (that is, employment ${ }^{\text {s6 }}$ or privacy ${ }^{5}$ ). In other states, legislators have indicated that there is a lack of understanding and legislative apathy concerning the issue of genetic discrimination.

\section{Policy considerations}

The development of public policy to address genetic information and health insurance must be analyzed in light of a complex and inadequate health insurance system, the uncertainty about the furure scope and impact of generic testing, and the political realities of a pluralistic sociery. The current patchwork of state legislative approaches does not provide a comprehensive solution to generic discrimination and health insurance. State laws focus narrowly on generic tests, rather than broadly on generic information generated by family history, physical examination, or the medical record. Although health insurers are prohibited from using the results of a chemical test of DNA, or the protein product of a gene, they can still use other phenotype indicators, patterns of inheritance of generic characteristics, or requests for genetic testing as the basis for discriminarion. ${ }^{58}$ Thus, "meaningful protection against genetic discrimination requires that insurers be prohibited from using all information about genes, gene products, or inherited characteristics to deny or limit health insurance coverage." $\$ 9$

Second, a large proportion of the population receives its health benefits from self-insured plans nor subject to state insurance laws. The ERISA preemption prevents a statewide approach to regulating the use of genetic informarion by all plans providing health benefits. Furthermore, no federal laws specifically address genetic discrimination in health insurance.

Recent health insurance proposals at both the state and federal level focus primarily on modest reform in the areas of accessibility, portability, and renewability of coverage, prohibiting insurers from denying coverage based on health status or medical condition, but often permitting exclusions for preexisting conditions for limited time periods. It is unclear whether and to what extent genetic information would be covered by these proposals. ${ }^{\circ}$ For example, unlike medical conditions, genetic information may provide insight into an individual's and/or family member's predisposition to future disease. ${ }^{61}$

With these policy considerations in mind, the following recommendations were developed by the Working Group on Ethical, Legal, and Social Implications of the Human Genome Project (ELSI) ${ }^{62}$ and the National Action Plan on Breast Cancer (NAPBC) ${ }^{63}$ as guidelines for both state and federal policy makers to protect against generic discrimination: ${ }^{64}$

(1) Insurance providers should be prohibited from using generic information, or an individual's request for genetic services, to deny or limit any coverage or to establish eligibility, continuation, enrollment, or contribution requirements.

(2) Insurance providers should be prohibited from establishing differential sates or premium payments 
based on genetic information, or an individual's request for genetic services.

(3) Insurance providers should be prohibited from requesting or requiring collection or disclosure of genetic information.

(4) Insurance providers and other holders of generic informarion should be prohibited from releasing generic information without prior written authorization of the individual. Written authorization should be required for each disclosure and include to whom the disclosure would be made.

The recommendations further provide that generic information be defined as "information about genes, gene producs, or inherited characteristics that may derive from the individual or a family member." ${ }^{\text {"ss }}$ Insurance provider is defined as "an insurance company, employer, or any other encity providing a plan of health insurance or health benefits including group and individual health plans whether fully insured or self-funded." 66

These recommendations evolved, in part, from a criti$\mathrm{cal}$ analysis of stare legislarive approaches. This analytical framework is intended to scimulate a comprehensive solution to generic. discrimination in health insurance ${ }^{7}$ that integrates both privacy protection and the reality that genetic information is much more than just a test result.

\section{Acknowledgments}

This article is adapted from a presentation at the workshop "Genetic Discriminarion and Health Insurance: A Case Srudy on Breast Cancer," sponsored by the Nacional Action Plan on Breast Cancer and the NIH-DOE Working Group on the Ethical, Legal, and Social Implications of Human Genome Research, July 11, 1995, Bethesda, Maryland.

I want to express my thanks to my research assistant, Barbara Fuller, for her outstanding contribution to this arvicle, the preparacion of Figures 1 and 2, and her total commirment to this research project. I also thank all the varsous state legislative officials, as well as Wendy McGoodwin of the Council for Responsible Genetics and Ann Rufo formerly of the National Center for Human Genome Research, for providing helpful insights and information. Finally, I thank my colleagues Kathy Hudson, Lori Andrews, Mary Jo Ellis Kain, and Francis Collins, who co-authored "Ge. netic Discrimination and Health Insurance: An Urgent Need for Reform," Science, 270 (1995): 391-93, for therr hard work and inspiration.

\section{References}

1. T.H. Murray, "Generics and the Moral Mission of Health Insurance," Hessings Center Report, 22, no. 6 (1992): 12-17.

2. "Genecic discrimination refers to diserimination direced against an individual or family based solely on an apparent or perceived genetic variation from the 'normal' human genotype." P.R Billings et al., "Discrimination as a Consequence of Genetic Texingo" Americen Joumal of Human Geneties, 50 (1992): at 476.

3. This is not to imply that fear of generic discrimination is nor an issue in the life and disability income insurance context as well. However, this arride, like most legislaive approaches to date, focuses on health insurance. But see Ariz Rev. Stat. Ann. S 20-448 (1989); and Mont. Code Ann 533-18-206 (1991) (life and disability insurance).

4. See Billings et al, supre note 2. See also $K$. Hudson er al., "Genecic Discrimination and Healh Insurance: An Urgent Need for Reform," Science, 270 (1995): 391-93.

5. Scare insurance reforms have addressed community rating, preexisting condition clauses, portability, guaranteed issue, and renewal. For a description of recent state legislative activity on health care reform, see generally K Ladenheim, L Lipson, and A. Markus, Health Care Reform: 50 State Profiles (Washington, D.C: George Washington Universiny Intergovernmental Health Policy Project, 1994); and D. Parde and C. Popolo, Health Care Reform in the States: A Special Report on State Health Care Reform Initiotives (Alexandria: Council for Affordable Health Insurance, 1994).

6. This summary is based on two excellent discussions describing healh insurance. See Advances in Genetic Information: A Guide for State Policy Makers (Lexington: Council of State Governments, 1993); and Genetic Information and Health Insurance (Bethesda: Task Force on Generic Information and Insurance, NIH-DOE Working Group on Ethical, Legal, and Social Implications of Human Genome Research, 1993).

7. See Hudson et ah, supra note 4 (aiting Employee Benefit Research Institute, Special Report SR-26, Issue Brief 158 (1995)).

8. See Hudson et al., supra note 4, at 392.

9. 29 U.S.C. (1974).

10. 15 U.S.C. S 1011 (1988). (1990).

11. 42 U.S.C. S $12101-12213$ (1990); and 42 U.S.C.S 12201

12. On March 15, 1995, the Equal Employment Opportuniry Commission clarified that "disability" applies to individuals who are subjected to discrimination on the basis of generic information relaring to illness, disease, or other disorders. To illustrate their policy furthes, one example of generie discriminanon based on genetic information concerns an individual with an increased susceptibility to colon cancer. Equal Employment Opportunity Commission, Compliance Manual Section 902: Definttion of the Term "Disability" (Mar. 15, 1995).

13. N.C. Gen. Srat. S 58-65-70 (1975).

14. Fia. Star. Ann. S 626.9707 (West 1978).

15. Md. Code Ann., Insur., S 223 (1986).

16. Id.

17. Cal. Insur. Code SS 10123.2, 10123.3, 10123.31, $10123.35,10140,10140.1,10140.5,10147,10148,10149$, $10149.1,11512.95,11512.96,11512.965$ (West 1994 \& West 1995): and Cal. Health \& Safery Code $\$ \$ 1374.7,1374.9$ (West 1994 \& Wiest 1995).

18. Col. Rev. Srat. S 10-3-1104.7 (1994).

19. Ga. Code Ann. S 33-54-1-8 (1995).

20. 1995 Minn. Laws 251.

21. 1995 N.H. Laws 101.

22. Ohio Rev. Code Ann. SS 1742.42, 1742.43, 3901.49, 3901.491, 3901.50, 3901.501 (Baldwin 1993).

23. 1995 Or. Laws 680.

24. S. 576 and S. 299, Haw. 18th Leg. (1995); and H. 1556, Haw. 18th Leg. (1995). 
25. H. 2251, Kan. Sess. (1995).

26. H. 4485, Mass. (1995).

27. H. 1662, P2. 179th Gen. Assembly (1995-96).

28. 1995 Or. Laws 680.

29. Cal. Insur. Code S 10147(b) (West 1994).

30. Wis. Sat Ann. S 631.89 (West 1991).

31. 1995 Minn. Laws 251.

32. Cal. Insar. Code S 10147(e) (West 1994).

33. 1995 N.H. Laws 101.

34. A. 227 , IS $2 \& 3$, Wis. Leg. (1995-96).

35. Id

36. 1995 N.H. Laws 101.

37. Id.

38. Wis. Sac Ann. 5 631.89(2)(b) (West 1991).

39. A. 227, Wis. Leg. (1995-96).

40. Special Comm. on Genetic and Medical Information, Wis. Joint Legis. Counsel (1994).

41. Cal. Insur. Code S 10149.1 (West 1994).

42. Colo. Rev. Sat. S 10-3-1104.7(3)(a) (1994).

(1995).

43. 1995 Or. Laws 680; and Ga. Ann. Code S 33-54-1(1)

44. Fla Star Ann. S 760.40 (West 1992).

45. Wis. Stat. Anr. 5631.89 (3)(b) (West 1991).

46. 1995 N.H. Laws 101.

47. 1995 Minn. Laws 251.

48. Id.

49. Cal. Insur. Code $\$ 10148(a)-(b)$ (West 1994).

50. H. 4485 S 1-E, Mass. (1995).

51. L Res. 467, Neb. (1994). In addition, both Nebraska and Massachuserts have bills pending to establish commissions to study the irtilization of genetic information. See L. 698, Neb. 94th Leg;, Ita Sess. (1995); and S. 2045, Mass. 179th Gen. Court, 1st Sess. (1995).

52. H. 71 S 3, Ohio 120th Gen. Assembly (1993) (enacted).

53. S.J. Res. 372, Va. Reg. Sess. (1994-95).

54. H. 343, Tex. (1995).

55. A 5892, N.Y. Reg. Sess. (1995).

56. A. 7839, N.Y. Reg. Sess. (1995-96).

57. A. 5796, N.Y. Reg. Sess. (1995-96).

58. See Hudison er al., supra nore 4, at 392.

59. Id.

60. See, for example, the Health Insurance Reform Act of 1995 (S. 1028), introduced by Senator Kassebaum on July 13,
1995. The Labor and Human Resources Committee on Senate Bill 1028 did state, however, that generic information is to be included in its prohibirions against denying coverage based on health scanus or medical history. The Clinton administration's proposal for health are reform did prohibit limicing access or coverage on the basis of "existing medical condicions or generic predisposition to medical conditions." Id. (citing the Health Security Act, S 1516, S. 1757/H.R. 3600).

61. Hudson et al., supra note 4, at 392.

62. The NIH-DOE EISI Working Group has a "broad and diverse membership including genome scientises; medical geneticists; experts in law, exhics and philosophy; and consumers, to explore and propose oprions for the development of sound professional and public policies related to human genome research and its applications." Id.

63. NAPBC is a "public-private parmership designed to eradicate breast cancer as a threar to the lives of American women," and it "has identified genetic discrimination in health insurance as a high priority." Id. at 393.

64. These recommendations have been endorsed by the National Advisory Council on Human Genome Research. Id.

65. Id.

66. Id. Furthermore, legislacion should provide enforcement mechanisms, including civil and criminal liability, to assure that insurance entities comply with these provisions. For example, as noted earlier, California provides that negligent and willful disclosure of generic test results without authorization is subject to civil and criminal liabiliry. Cal. Insur. Code $\$ 10147$ (b) (1994).

67. Since November 1995, a few federal bills that address generic discrimination and privacy have been introduced; they include the Genetic Privacy and Nondiscrimination Act of 1995 (S. 1416), introduced by Senator Hatfield, and a similar bill (H.R. 2690), introduced by Representarive Stearns. In addition, Representative Slaughter introduced the Genetic Information Nondiscrimination in Health Insurance Act of 1995 (H.R 2748), which integrates the four recommendations developed by ELSI and NAPBC. Senator Feinstein is also considering the introduction of similar insurance legislation in the Senare. With respect to privacy, Senator Bennetr has introduced the Medical Records Confidentiality Act of 1995 (S. 1360), which generally addresses health information and privacy, but does not specifically consider genecic information. 